\title{
EFFECT OF PHOSPHORUS AND SULPHUR FERTILIZATION ON THE NUTRITIVE VALUE OF SUBTERRANEAN CLOVER (TRIFOLIUM SUBTERRANEUM) *
}

\author{
M. B. Jones, J. H. OH, AND J. E. Ruckman $\uparrow$
}

\section{Summary}

Phosphorus or sulphur applied alone to a soil deficient in $\mathrm{P}$ and $\mathrm{S}$ did not increase subterranean clover (Trifolium subterraneum) yields; but when the two elements were applied together, a five-fold increase was obtained. The nutritive value of the clover was evaluated by measuring sheep rumen microbial activity using an anaerobic manometric technique. Subterranean clover fertilized with $\mathrm{P}$ alone increased the microbial activity about $6 \%$. In contrast, the clover fertilized with $\mathrm{S}$ alone decreased activity about 5\%. When $\mathrm{P}$ and $\mathrm{S}$ were applied together, microbial activity was increased 20 to $30 \%$, depending on the rates applied. There was a positive correlation between the level of reducing sugars in the clover and the degree of rumen microbial activity.

Applications of phosphorus and sulphur to deficient soils of California annual grasslands have generally resulted in striking increases in yields and pronounced changes in botanical and chemical composition of the forage. From work reported with other forage crops (Rendig and Weir, 1957; Weir, et al., 1958; Reid and Jung, 1965) it has been assumed that these changes improved the quality of the crop, but no direct measurements of quality have been made.

On annual grasslands it is difficult to obtain sufficient amounts of a single plant species to run digestion studies, especially at variable levels of soil fertility. Rumen microbial gas production, measured in vitro, has been shown to be highly correlated with dry matter intake and dry matter digestibility (Oh, et al., 1969). Such techniques make it easier to study the changes in nutritive value which accompany changes in soil fertility, and it is possible to include in a study a greater number of fertility levels than would be practical under field conditions.

* Contribution of the Departments of Agronomy and Range Science, and Zoology, University of California, Hopland and Davis. This work was supported in part by the Sulphur Institute.

$\dagger$ Agronomist, Assistant Research Bacteriologist, and Associate Specialist, respectively. 
The purpose of this study was to determine relative nutritive values of subterranean clover grown at various levels of soil $\mathrm{P}$ and $\mathrm{S}$.

\section{PROCEDURE}

In a glasshouse, $2 \mathrm{~kg}$ of Josephine soil, known from previous experimentation to be very deficient in $\mathrm{P}$ and $\mathrm{S}$, and not responsive to applications of micronutrients, were placed in each of 64 plastic pots. Four levels of $\mathrm{P}(0,25$, 50 , and $75 \mathrm{ppm}$ ) were applied as $\mathrm{H}_{3} \mathrm{PO}_{4}$ in all combinations with four levels of $\mathrm{S}(0,5,10$, and $15 \mathrm{ppm})$ applied as $\mathrm{H}_{2} \mathrm{SO}_{4}$. Each pot also received $50 \mathrm{ppm} \mathrm{K}$ as $\mathrm{KCl}$. All fertilizers were applied in solution and, after drying, were mixed throughout the soil. Then, the soil was tested for $\mathrm{P}$ by the sodium bicarbonate method (Olsen et al., 1954). On February 24, 1969, 15 inoculated seeds of subterranean clover (Trifolium subterraneum 'Clare') were planted in each pot. Treatments were replicated four times.

The pots were weighed periodically throughout the growing period, and were watered as needed to maintain the soil moisture near field capacity. On May 2, when the clover was in flower, all forage was harvested, ovendried at $68^{\circ} \mathrm{C}$, weighed, and ground to pass a 40-mesh screen.

With $0.1 \mathrm{~g}$ subterranean clover as substrate, rumen microbial activity was measured by the Warburg manometric technique of Hungate et al. (1955) as modified by Oh et al. (1967). The ruminal inoculum was obtained, as follows, from sheep maintained on good quality lucerne hay. Ruminal fluid was strained through two layers of cheesecloth, and then centrifuged at $300 \mathrm{rpm}$ for 45 seconds to remove large feed particles. The supernatant fluid was retained and centrifuged at $20,000 \mathrm{rpm}$ for 15 minutes. This supernatant fluid was discarded, and the sedimented ruminal microbes were suspended in a buffer of $1.2 \% \mathrm{NaHCO}_{3}$ and $0.6 \% \mathrm{NaCl}$, preheated to $39^{\circ} \mathrm{C}$. Seven $\mathrm{ml}$ of the microbial solution was used to ferment the substrate for 24 hours. Microbial activity was expressed as mmoles gas $/ 0.1 \mathrm{~g}$ substrate.

Total N, P, and $\mathrm{S}$ in the forage were estimated, respectively, by the methods of AOAC (1965) ; Bridger et al. (1953) and Johnson and Nishita (1952) . Carbohydrates were determined by the AOAC (1965) method as modified by Hassid (1936), and McCready et al. (1950).

\section{RESULTS}

The results are indicated in Table 1 . Neither $\mathrm{P}$ nor $\mathrm{S}$ applied without the other produced a significant effect on 
yield. Application of $25 \mathrm{ppm}$ or more $\mathrm{P}$ plus $5 \mathrm{ppm}$ or more $S$ caused about a five-fold increase in yield. Soil tested by the sodium bicarbonate method for available $\mathrm{P}$ gave values of $2,8,15$, and $23 \mathrm{ppm} \mathrm{P}$ for the $0,25,50$, and 75 ppm treatments, respectively.

The concentration of $\mathrm{P}$ in the dried clover was about $0.09 \%$ when no $\mathrm{P}$ or $\mathrm{S}$ was applied. Adding 25 to $75 \mathrm{ppm}$, $\mathrm{P}$ but no $\mathrm{S}$, nearly doubled the level. However, when $\mathrm{S}$ was applied, only a small significant increase in plant $\mathrm{P}$ was observed with $25 \mathrm{ppm} \mathrm{P.} \mathrm{An} \mathrm{additional} \mathrm{increase} \mathrm{occurred}$ with each increment of $\mathrm{P}$ added. Percentage $\mathrm{S}$ in the clover increased as the amount of $\mathrm{S}$ applied increased, but application of $25 \mathrm{ppm} \mathrm{P}$ reduced the $\mathrm{S}$ percentage. Additional increments of $\mathrm{P}$ had little effect on $\mathrm{S}$ percentages except at the $15 \mathrm{ppm} \mathrm{S}$ level, $50 \mathrm{ppm} \mathrm{P}$ increments reduced $\mathrm{S}$. The concentration of $\mathrm{N}$ in the clover was decreased by the first increment of $\mathrm{P}$ and increased by the first two increments of $\mathrm{S}$, with little difference at higher $\mathrm{P}$ and $\mathrm{S}$ levels.

The percentage of reducing sugars in the plants was not significantly changed by the addition of either $\mathrm{P}$ or $\mathrm{S}$ alone; but with the addition of at least $25 \mathrm{ppm} \mathrm{P}$ the first two increments of $\mathrm{S}$ increased reducing sugar. With the addition of $\mathrm{S}$, only the first increment of $\mathrm{P}$ increased reducing sugar.

Application of $15 \mathrm{ppm} \mathrm{S}$ alone reduced sucrose percentage in the clover, but applying $\mathrm{S}$ with $25 \mathrm{ppm}$ or more $\mathrm{P}$ increased sucrose. Phosphorus applications increased sucrose only where $\mathrm{S}$ had been applied.

Percentage starch in the clover was increased by the first increment of $\mathrm{P}$ only, and was decreased by the first two increments of $\mathrm{S}$.

Microbial gas production was increased by the application of $\mathrm{P}$ only, but was reduced when $\mathrm{S}$ only was applied. There was an increase in gas production with the first $5 \mathrm{ppm}$ increment of $\mathrm{S}$ where $25 \mathrm{ppm} \mathrm{P}$ had been applied, but, where 50 and $75 \mathrm{ppm}$ had been applied, an increase in gas production resulted from applications of 5 and 10 ppm S.

\section{DISCUSSION AND CONCLUSIONS}

There are two factors involved in changing the rates of rumen microbial activity induced by $\mathrm{P}$ and $\mathrm{S}$ fertilization: (1) the $\mathrm{P}$ and $\mathrm{S}$ requirements for growth of the microbes; and (2) other chemical changes in the plants, such as concentration of reducing sugars, resulting from fertilization,

There are apparent critical levels of $\mathrm{P}$ and $\mathrm{S}$ in plant tissue, below which rumen microbial activity decreases 
TABLE 1: EFFECT OF P AND S FERTILIZATION ON YIELD, CHEMICAL COMPOSITION, AND NUTRITIVE VALUE OF SUBTERRANEAN CLOVER AS INDICATED BY RUMEN MICROBIAL GAS PRODUCTION

\begin{tabular}{|c|c|c|c|c|c|c|c|c|c|c|}
\hline \multicolumn{2}{|c|}{$\begin{array}{c}\text { Fertilizer } \\
P \quad \mathrm{~S} \\
(\mathrm{ppm}) \\
\end{array}$} & $\begin{array}{c}\text { Yield } \\
(\mathrm{g} / \text { pot })\end{array}$ & $\begin{array}{c}P \\
(\%)\end{array}$ & $\underset{(\%)}{S}$ & $\begin{array}{l}N \\
\%)\end{array}$ & $N / S$ & $\begin{array}{l}\text { Reducing } \\
\text { Sugar as } \\
\text { Glucose } \\
\quad(\%)\end{array}$ & $\begin{array}{c}\text { sucrose } \\
(\%)\end{array}$ & $\begin{array}{c}\text { Starch } \\
(\%)\end{array}$ & $\begin{array}{c}\text { Rumen } \\
\text { Microbial } \\
\text { Gas } \\
\text { Production } \\
\text { (moles/0.1 } \\
\text { g) } \\
\end{array}$ \\
\hline 0 & & & & & & & & & & $0.12 \mathrm{~b}$ \\
\hline 0 & 10 & 2.06 .110 & 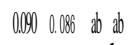 & $0.153 \quad 0.060 \quad$ fgc 1.941 .61 & $g$ ef & 111.3 & I.1. & 1.11.bcdde & $142.10 .3 \mathrm{~cd} \mathrm{a}$ & $0.66 \quad \mathrm{a}$ \\
\hline 0 & 10 & $2.3 \mathrm{a}$ & $0.085 \mathrm{ab}$ & $0.168 \mathrm{gh} 2.02$ & $g$ & 12 & $1.1 \mathrm{a}$ & 7.7 cde & $10.2 \mathrm{a}$ & $0,65 \mathrm{a}$ \\
\hline 0 & 15 & $2.3 \mathrm{a}$ & $0.083 \mathrm{a}$ & $0.188 \mathrm{~h} \quad 2.00$ & $\mathrm{~g}$ & 11 & $1.3 \mathrm{a}$ & $.5 .1 \mathrm{a}$ & $10.5 \mathrm{a}$ & $0,67 \mathrm{a}$ \\
\hline 25 & 0 & $2.9 \mathrm{a}$ & $0.161 \mathrm{e}$ & 0.035 a 1.39 & $a b$ & 40 & $1.3 \mathrm{a}$ & $6.2 \mathrm{abc}$ & $20.2 \mathrm{~g}$ & $0.78 \mathrm{c}$ \\
\hline 25 & 5 & $10.7 \mathrm{bc}$ & $0.109 \mathrm{c}$ & $0.053 \quad b \quad 1.47$ & $\mathrm{bc}$ & 28 & $4.4 \mathrm{~cd}$ & $9.2 \mathrm{ef}$ & $17.1 \mathrm{f}$ & $0.92 \mathrm{~d}$ \\
\hline 25 & 10 & $11.8 \quad b-\mathrm{e}$ & $0.101 b c$ & $0.094 \mathrm{de} 1.58$ & def & 17 & 5.1 def & $9.0 \mathrm{ef}$ & 14.6 cde & $0.96 \mathrm{de}$ \\
\hline 25 & 15 & $10.5 \mathrm{~b}$ & $0.108 \mathrm{c}$ & 0.132 f 1.54 & cde & 12 & $4.5 \mathrm{de}$ & $8.2 \mathrm{def}$ & 14,5 cde & $0.94 \mathrm{~d}$ \\
\hline $\begin{array}{l}50 \\
50\end{array}$ & $\begin{array}{l}0 \\
5\end{array}$ & $\begin{array}{c}3.4 \text { a } \\
12.4 \text { cde }\end{array}$ & $\begin{array}{l}0.161 \mathrm{e} \\
0.158 \mathrm{de}\end{array}$ & $\begin{array}{l}0.037 \text { ab } 1.37 \\
0.052 \text { abc } 1.49\end{array}$ & $\stackrel{\mathrm{a}}{\mathrm{cd}}$ & $\begin{array}{l}37 \\
29\end{array}$ & $\begin{array}{l}1.2 \mathrm{a} \\
3.5 \mathrm{~b}\end{array}$ & $\begin{array}{l}6.2 \mathrm{abc} \\
9.8 \mathrm{f}\end{array}$ & $\begin{array}{l}20.8 \mathrm{~g} \\
15.1 \mathrm{de}\end{array}$ & $\begin{array}{l}0.81 \mathrm{c} \\
0.96 \mathrm{de}\end{array}$ \\
\hline 50 & 10 & $14.8 \mathrm{fg}$ & $0.142 \mathrm{~d}$ & $0.084 \quad d \quad 1.56$ & cde & 19 & 5.3 ef & $8.3 \mathrm{def}$ & $13.3 \mathrm{bc}$ & $1.01 \mathrm{ef}$ \\
\hline 50 & 15 & $12.9 \mathrm{de}$ & $0.161 \mathrm{e}$ & 0.108 e 1.62 & ef & 15 & $5.4 \mathrm{f}$ & 7.6 cde & 14.4 cde & $1.01 \mathrm{ef}$ \\
\hline 75 & 0 & $3.2 \mathrm{a}$ & $0.176 \mathrm{ef}$ & $0.036 \quad a b \quad 1.36$ & $a$ & 38 & $1.3 \mathrm{a}$ & $5.8 \mathrm{ab}$ & $20.8 \mathrm{~g}$ & $0.77 c$ \\
\hline 75 & 5 & $11.6 \mathrm{bcd}$ & $0.200 \mathrm{~g}$ & 0.058 bc 1.49 & $\mathrm{~cd}$ & 26 & $3.7 \mathrm{bc}$ & 9.0 ef & $15.4 \mathrm{e}$ & $0.93 \mathrm{~d}$ \\
\hline 75 & 10 & $13.6 \mathrm{ef}$ & $0.196 \mathrm{~g}$ & 0.090 de 1.69 & $\mathrm{f}$ & 19 & $4.9 \mathrm{def}$ & $7.9 \mathrm{de}$ & $13.0 \mathrm{~b}$ & $1.03 \mathrm{f}$ \\
\hline 75 & 15 & $15.9 \mathrm{~g}$ & $0.192 \mathrm{fg}$ & 0.107 de 1.55 & cde & 14 & $5.5 \mathrm{f}$ & 8.6 def & 14.5 cde. & $1.04 \mathrm{f}$ \\
\hline
\end{tabular}

Values within a column followed by the same letter are not significantly different at the $5 \%$ level. 
sharply when such plants are used as microbial substrate. Under the conditions of this experiment, these critical levels were $0.10 \%$ for $\mathrm{P}$ and $0.05 \%$ for $\mathrm{S}$. Below these levels it appears that $\mathrm{P}$ or $\mathrm{S}$ were primary limiting factors. However, levels of reducing sugars were also lowest where $P$ and $S$ values were lowest. Thus, critical levels cannot be taken at face value. There was a small increase in microbial activity where $\mathrm{P}$ level went from 0.10 to about $0.14 \%$ at the two higher levels of $\mathrm{S}$. Above this range there was no further increase. Likewise, small increases occurred when $\mathrm{S}$ level went from 0.05 to about $0.08 \%$ at the two higher levels of $\mathrm{P}$. The care used in eliminating all $\mathrm{P}$ and $\mathrm{S}$ from the buffer solution and as much as possible from the inoculum, so that the only source of the two elements was the clover substrate, had an important influence on the results.

There was a positive correlation between microbial activity and the percentage of reducing sugars, except when $\mathrm{P}$ and $\mathrm{S}$ were most limiting. The relation of rumen microbial activity to concentration of sucrose was less intimate than to reducing sugars, although correlation coefficient values for sucrose were significant at some levels of $\mathrm{P}$ and $\mathrm{S}$.

Above the $\mathrm{P}$ and $\mathrm{S}$ critical levels there was a negative correlation between microbial activity and starch percentage. The diet of the sheep providing ruminal inoculum has an influence on the characteristics of fermentation (Baumann and Foster, 1956). Had the sheep been on a grain diet rather than lucerne, this correlation may have been positive.

It is not surprising that percentage $\mathrm{N}$ in the clover was not well correlated with ruminal activity, since applied $\mathrm{P}$ decreased the $\mathrm{N}$ level and increased activity, while applied $\mathrm{S}$ increased both $\mathrm{N}$ and ruminal activity. However, it is surprising that the level of $\mathrm{N}$ in the clover was so low. It is not probable that additional increments of $S$ would have increased the level of $\mathrm{N}$, since the last increment of $\mathrm{S}$ applied did not increase $\mathrm{N}$ level in the plant. Subsequent tests have indicated that the strains of rhizobia used in this study were less effective $\mathrm{N}$ fixers than strains now available. Possibly this is the reason for low $\mathrm{N}$ values.

The information from this study supports the findings of Weir et al. (1958) who reported that lucerne hay which contained $0.10 \% \mathrm{P}$ produced poor animal gains compared with hay containing $0.15 \% \mathrm{P}$. Values reported by Reid and Jung (1965) were far higher, $0.38 \% \mathrm{P}$ for superphosphate fertilized fescue compared with $0.34 \% \mathrm{P}$ for unfertilized grass. Sheep 'preferred the fertilized grass. 
The $S$ percentages in this study were generally lower than the hay studied by Rendig and Weir (1957), who indicated that animals performed better when fed hay containing $0.18 \% \mathrm{~S}$ rather than hay with $0.14 \% \mathrm{~S}$.

The very low $\mathrm{P}$ and $\mathrm{S}$ levels reported in the forage of this study have been found under field conditions on the annual grasslands of California. Therefore, the low concentrations of $\mathrm{P}$ and $\mathrm{S}$ probably adversely affect the quality of feed as well as total production under field conditions. The addition of $\mathrm{P}$ and $\mathrm{S}$ fertilizers to these very deficient grasslands not only increases forage production when legumes are present, but evidence indicates that the nutritive value of that forage also is increased by both elements.

\section{REFERENCES}

AOAC, 1955: O fficial Methods of Analysis, 10th ed. Method 2.044 6.074 (b), 6.075 (a), and 29.026 (c).

Bauman, H. E.; Foster, E. M., 1956: Characteristics of organisms isolated from the rumen of cows fed high and low roughage rations. J. Bact., 71: 333.

Bridger, G. L.; Boyland, D. R.; Markey, J. W., 1953: Colorimetric determination of phosphorus pentoxidz in fertilizers using a standard calibration plot. Analyt. Chem., 25: 336-8.

Hassid, W. Z., 1936: Determination of reducing sugars and sucross in plant material. Ind. Eng. Chem., Anal. Ed. 8: 138-40.

Hungate, R. E.; Fletcher, D. W.; Dougherty, R. W.; Barrentine, B. F., 1955: Microbial activity in the bovine rumen: Its measurement and relation to bloat. Appl. Microbiol., 3: 161.

Johnson, C. M.; Nishita, H., 1952: Microestimation of sulfur. Analyt. Chem., 24: 736-42.

McCready, R. M.; Guggolz, J.; Silviera, V.; Owens, H. S., 1950: Determination of starch and amylase in vegetables. Ibid., 22: 1156-8.

Oh, H. K.; Longhurst, W. M.; Jones, M. B., 1969: Relation of nitrogen intake to rumen microbial activity and consumption of low-quality roughage by sheep. J. Anim. Sci., 28: 272-8.

Oh, H. K.; Sakai, T.; Jones, M. B.; Longhurst, W. M., 1967: Effect of various essential oils isolated from Douglas fir needles upon sheep and deer rumen microbial activity. Appl. Microbiol., 15: $777-84$.

Olsen, S. R.; Cole, C. V.; Watanabe, F. S.; Dean, L. A., 1954: Estimation of available phosphorus in soils by extraction with sodium bicarbonate. U.S. Dept. of Agric. Circ, No. 939.

Reid, R. L.; Jung, G. A., 1965: Influence of fertilizer treatment on the intake, digestibility, and palatability of tall fescue hay. $J$. Anim. Sci., 24: 615-25.

Rendig, V. V.; Weir, W. C., 1957: Evaluation by lamb feeding tests of alfalfa hay grown on a low-sulfur soil. Ibid., 16: 451-61.

Weir, W. C.; Rendig, V. V.; Ittner, N. R., 1958: Evaluation by lamb and steer feeding tests of alfalfa hay of varying phosphorus content. Ibid., 17: 113-23. 


\section{DISCUSSION}

Howard asked if gas production had been correlated with reducing sugars and starch together, to which Jones replied that., when reducing sugars were added to sucrose, a similar pattern was obtained.

Bailey suggested that the starch levels were high by New Zealand standards and asked how they were obtained. Jones said the old classical chemical methods had been used. He had extracted sugars, reducing sugars and then sucrose. The remaining starch was hydrolysed to sugar and measured in this way. The level was higher than expected but other methods had verified the results. It could! be that the level was affected by low $\mathrm{N}$ content and the fact that the material was grown indoors.

Smith (U.S.A.) thought it might be possible that photosynthesis had been restricted in the plants because they were grown at too low temperatures. Jones replied that the plants grew over the period February-May, with day temperatures 80 to $90^{\circ} \mathrm{F}$ and night $50^{\circ} \mathrm{F}$. Smith further commented that any factor slowing down growth could cause accumulations so temperatures could have an effect. Jones agreed that the same situation could. occur in the field where drought conditions would cause accumulations.

Ludecke considered that even at the high levels sulphur could still be deficient and asked if a greater growth response would be achieved at higher rates of sulphur. Jones said he would certainly use higher levels of $S$ in further trials. In the present trial they had wanted to find the critical level.

Asked by Katznelson (Israel) if fertilizers had affected the phenology of the plant, Jones replied that flowering had been earlier with phosphorus but no such effect had been noticed from sulphur. 